\title{
The effect of land uses and rainfall regimes on runoff and soil erosion in the semi-arid loess hilly area, China
}

\author{
Wei Wei ${ }^{a, b}$, Liding Chen ${ }^{a, *}$, Bojie Fu ${ }^{a}$, Zhilin Huang ${ }^{c}$, Dongping Wu ${ }^{d}$, \\ Lida Gui ${ }^{d}$
}

a State Key Laboratory of Urban and Regional Ecology, Research Center for Eco-Environmental Sciences, Chinese Academy of Sciences, Beijing 100085, China

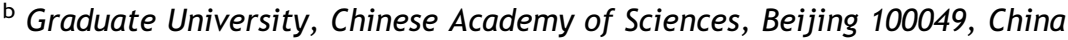

c Chinese Academy of Forestry, Beijing 100091, China

${ }^{d}$ Dingxi Institute of Soil and Water Conservation, Dingxi, Gansu Province 743000, China

Received 30 April 2006; received in revised form 21 November 2006; accepted 23 November 2006

\section{KEYWORDS}

Runoff and soil erosion;

Rainfall regime;

Clustering;

Land use;

Loess hilly area
Summary The main purpose of this article is to analyze runoff and soil loss in relation to land use and rainfall regimes in a loess hilly area of China. Based on 14 years of field measurements and $\mathrm{K}$-means clustering, 131 rainfall events were classified into three rainfall regimes. Rainfall Regime II is an aggregation of rainfall events with such features as high intensity, short duration and high frequency. Regime $I$ is the aggregation of rainfall events of medium intensity, medium duration and less frequent occurrence. Regime III is the aggregation of events of low intensity and long duration and infrequent occurrence. The following results were found. (1) Mean runoff coefficient and erosion modulus among the five land use types are: cropland > pastureland $>$ woodland $>$ grassland $>$ shrubland. (2) The sensitivity of runoff and erosion to the rainfall regimes differ. Rainfall Regime II causes the greatest proportion of runoff and soil loss, followed by Regime I and Regime III. (3) The processes of runoff and soil loss, however, are complicated and uncertain with the interaction of rainfall and land use. This is mainly due to the different stages of vegetation succession. Based on these results, it was suggested that more attention should be paid to Rainfall Regime II since it had the most erosive effect. Shrubland is the first choice to control soil erosion when land use conversion is implemented, whereas pastureland (alfalfa) is not. Large-scale plantation of alfalfa therefore, should be avoided. Grassland and woodland can be used as important supplements to shrubland.

(c) 2006 Elsevier B.V. All rights reserved.

\footnotetext{
* Corresponding author. Tel.: +86 10 62943840; fax: +861062923557.

E-mail addresses: chenliding@sohu.com, liding@rcees.ac.cn (L. Chen).
} 


\section{Introduction}

Soil erosion, defined as the detachment and displacement of soil particles from the surface to another location (Govers et al., 1990; Flanagan, 2002), continues to be a primary cause of soil degradation throughout the world (Fu and Gulinck, 1994), and has become an issue of significant and severe societal and environmental concern (Elsen et al., 2003; Singha et al., 2006). Land use/cover, as one of the most important factors, influences the occurrence and the intensity of runoff and sediment yield (Hovius, 1998; Karvonen et al., 1999; Chen et al., 2001). Non-uniform variations in land use/vegetation coverage proved to be closely related to hydrological responses over catchments (Siriwardena et al., 2006). By properly adjusting of land use/land cover patterns, soil properties can be greatly improved, consequently reducing soil erosion to the allowed threshold ( $\mathrm{Fu}$, 1989; Chen et al., 2003), and the improved soil physical properties can also positively affect the establishment of vegetation (Kosmas et al., 2000). On the other hand, improper land use and/or cover patterns can cause severe water, soil and nutrient losses, and further land degradation (Luk et al., 1989; Costa et al., 2003).

Runoff and erosion processes, however, are strongly affected by many other factors besides land use/land cover. Among these factors, the one most mentioned is rainfall. Rainfall can cause soil erosion and runoff when it reaches the ground (Sharma et al., 1993; Dijk et al., 2002; Kinnell, 2005). Also, the spatiotemporal heterogeneity and uneven characteristics of rainfall play a key role in soil erosion ( $\mathrm{Li}$ et al., 2000; Nearing, 2001; Bürger, 2002; Endale et al., 2006). Morin et al. (2006) found that complex interactions exist between the spatiotemporal distributions of rainfall systems and watershed hydrological responses. Local storm patterns are important in determining the shape of the runoff hydrograph (de Lima and Singh, 2002). Runoff and sediment generation in different land use types may thus vary greatly with various rainfall types. Addressing the response of runoff/erosion to different land use/land cover types and different rainfall types is therefore important for land use structure adjustment and vegetation restoration.

Rainfall classification, however, is an important problem, which needs to be solved. Most studies focused on the response of the runoff/erosion process to single rainfall pattern and different vegetation types (Yeh et al., 2000; de Lima et al., 2003; Kirkby et al., 2005). Undoubtedly, controlling soil erosion requires much more detailed and accurate data in the real world (Elsen et al., 2003). Many studies, however, are based on rainfall simulations, and thus the conclusions are often not applicable to the real world. For example, some authors have suggested that the nozzles of rainfall simulators produce low kinetic energies relative to natural rainfall (Luk et al., 1986). Madden et al. (1998) also found that the kinetic energy and erosivity of rainfall produced by simulators could be lower than that of natural rainfall. This insufficiency of energy plays an important role in infiltration capacity, preventing surface crusting and sediment detachment (Mathys et al., 2005). Other results also show that rainfall simulators are unable to reproduce natural rainfall conditions (Aizen et al., 2000; Mazi et al., 2004; Nearing et al., 2005). Accordingly, finding real rainfall-run- off-sediment patterns based on measurements are important for soil erosion control.

Soil loss and runoff studies at plot scales have been confirmed to be of crucial importance (Licznar and Nearing, 2003). Reliable and consistent erosion measurements and extensive field data have played primary roles in soil erosion analysis and prediction on larger scales (Zhang et al., 1996; Nearing et al., 1999). In addition, soil properties are always affected by land uses/vegetation evolution over long time scales (e.g., months-centuries), which then further influence runoff and soil erosion (Eagleson, 1982; Xu, 2005). For example, the accumulation of litter under plants contributes to increased surface roughness, higher infiltration rates, and decreased runoff generation thresholds (Boer and Puigdefábregas, 2005). Bochet et al. (1999) also found that topsoil modification and erosion processes are mainly due to the differential influences of species morphology (i.e., aboveground structure) and components (i.e., litter cover and organic matter). Moreover, the impact of plant roots on soil resistance to erosion by water is also significant (Hou, 1990; Zou et al., 2000; Gyssels et al., 2005; Mao et al., 2006). In general however, these kinds of long-term consecutive studies in arid and semi-arid areas are relatively scarce.

In this study, based on 14 years of field measurements in plots in a semi-arid loess hilly area, 131 rainfall events that produced runoff were recorded. On the basis of rainfall depth, duration and maximum 30-min intensity, all the events were classified into three categories. They were then used to analyze the effects of varying land uses and rainfall regimes on runoff and soil erosion. The specific objectives were: (1) to analyze the effects of land use/land cover on soil and water loss, (2) to determine the response of runoff and soil erosion to different rainfall regimes, and (3) to study the role of different land use types on soil erosion control under different rainfall regimes.

\section{Material and methodology}

\section{Study area}

Our experiments were all conducted in a small catchment, Anjiapo Catchment, Dingxi, Gansu province, China $\left(35^{\circ} 35^{\prime} \mathrm{N}, 104^{\circ} 39^{\prime} \mathrm{E}\right)$ in the middle reaches of the Yellow River (Fig. 1). This region is dominated by a temperate terrestrial climate with warm-humid summers and colddry winters. The average annual precipitation is about $427 \mathrm{~mm}$, of which more than $80 \%$ falls from May to September. The potential annual transpiration, however, can reach $1510 \mathrm{~mm}$. The mean monthly temperature ranges from $-7.6^{\circ} \mathrm{C}$ to $27.5^{\circ} \mathrm{C}$, with an average annual temperature of $6.3^{\circ} \mathrm{C}$. Approximately 141 days annually are frostfree.

Local soil develops from wind-accumulated loess parent material, which is about $40-60 \mathrm{~m}$ on depth. The dominant soil in the region belongs to calcic Cambisol (FAO-UNESCO, 1974) with clay of $33.12-42.17 \%$, organic matter of $3.7-$ $13.4 \mathrm{~g} / \mathrm{kg}$, and soil density is from 1.09 to $1.36 \mathrm{~g} \mathrm{~cm}^{-3}$ within $2 \mathrm{~m}$ depth (Huang et al., 2005). This type of soil has week resistant to erosion (Fu and Gulinck, 1994). Vegetation in the study area is poor due to lack of water. The dominant 


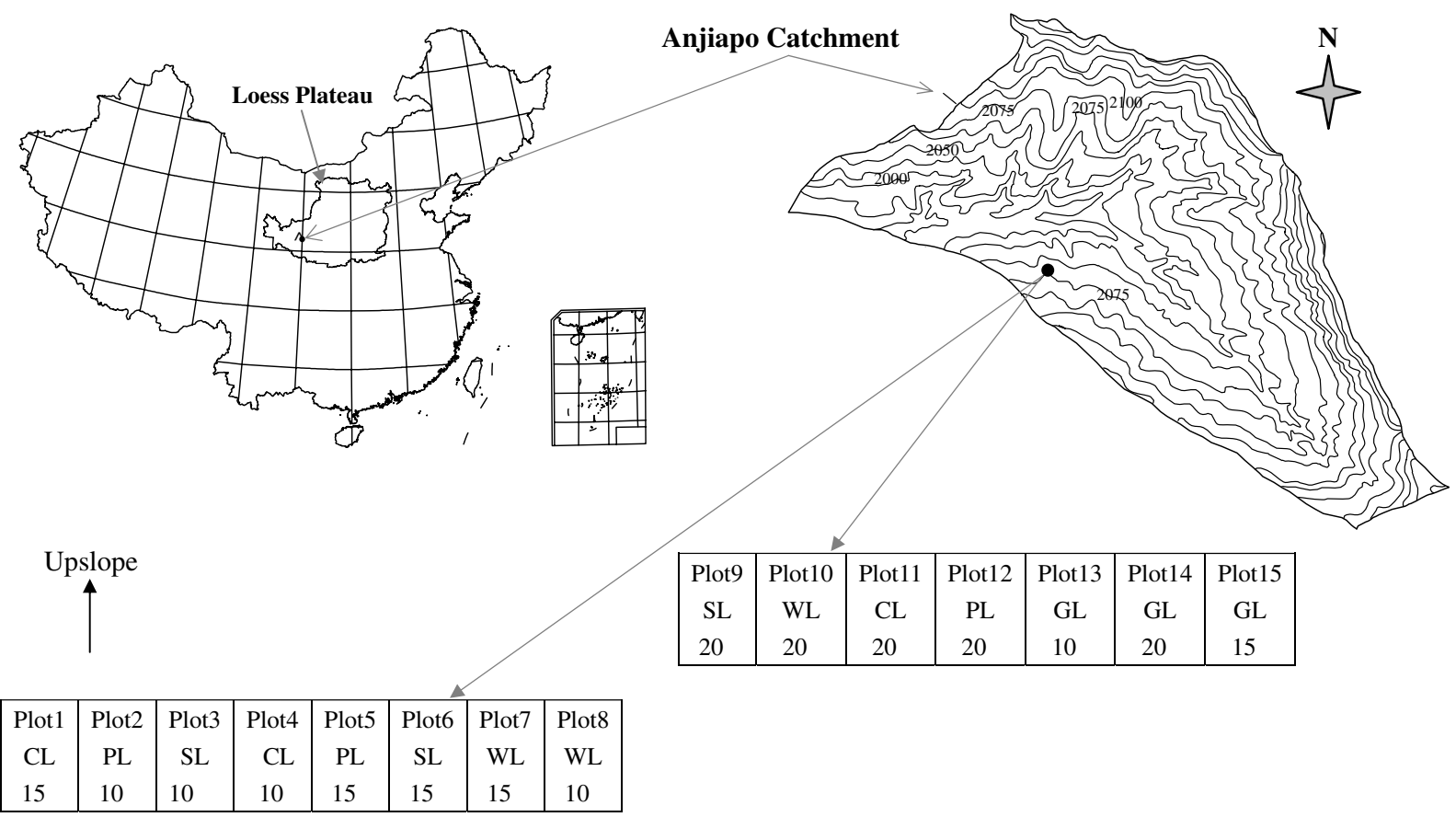

Figure 1 Study area and configuration of the plots in Anjiapo catchment, Dingxi, Gansu province. Note: CL, cropland; PL, pastureland; SL, shrubland; WL, woodland; GL, grassland. Three slope degrees: $10^{\circ}, 15^{\circ}, 20^{\circ}$.

plant species are: Chinese pine (Pinus tabuliformis Carr.), seabuckthorn (Hippophae rhamnoides L.), pea shrub (Caragana kansuensis Pojark.), Chinese arborvitae (Platycladus orientalis L.), apricot (Prunus armeniaca L.), alfalfa (Medicago sativa L.), sainfoin (Onobrychis vichfolia Scop.), and bunge needlegrass (Stipa bungeana Trin.). The main crop species are potatoes (Solanum tuberosum L.), spring wheat (Triticum aestivum L. cv Leguan), maize (Zea mays L.) and flax (Linum usitattissimum L.).

\section{Experimental design}

Fifteen experimental plots (Fig. 1) were planted on northfacing hill-slopes, on which rain-fed crops (wheat, potatoes, beans and millet) were grown before the plots were established. To reduce the effects of position, all plots were established on the same slope. They were oriented parallel to the slope and adjacent to each other.

The following five land cover types with three replications $\left(10^{\circ}, 15^{\circ}\right.$ and $\left.20^{\circ}\right)$ in the experimental plots were investigated. (1) Cropland (Triticum aestivum L. cv Leguan): Field management was similar to that used by local farmers, and the seeds of spring wheat were sown in April and harvested manually in early August. (2) Pastureland (Medicago sativa L.): The seed was drilled or broadcasted in April and harvested in late July. Alfalfa was replanted annually from 1993 to 1999 due to low yield. (3) Shrubland (Hippophea rhamnoides L.): Saplings of sea buckthorn were planted in $1.0 \mathrm{~m}$ by $1.0 \mathrm{~m}$ spacing in March, 1986. The litter remained on the plots during the experiment. (4) Woodland (Pinus tabulaeformis Carr.): Saplings of Chinese pine were planted in $3.0 \mathrm{~m}$ rows and $1.5 \mathrm{~m}$ columns in March, 1986. (5) Grassland (Stipa bungeana Trin.): This natural species was left to grow without human disturbance.
Plots used for shrubland and woodland were $10 \mathrm{~m} \times 10 \mathrm{~m}$, while plots used for slope cropland, pastureland and grassland were $10 \mathrm{~m} \times 5 \mathrm{~m}$. In each plot, cement ridges $(30 \mathrm{~cm}$ above ground) were constructed at the borders to isolate plot runoff and sediment. A discharge ditch was created at the top of each plot to control runoff and sediments from the upper slope. At the base of each plot, a marked $\mathrm{H}$-flume and two volumetric tanks were built at the outlet of each plot for surface runoff and sediments collection.

Precipitation during the rainy season was measured by a $\mathrm{SM}_{1}$ pluviometer and a $\mathrm{SJ}_{1}$ auto-siphon udometer. The depth, duration and intensity of each rainfall event were recorded. The runoff and erosion of each rainfall event were monitored. In total, 131 rainfall events with runoff (19861999) were recorded.

The possible initial spatial variations of runoff/erosion effects caused by slope aspect, slope position, elevation, and the physiochemical features of local soil were not considered, since all the plots were situated in a similar environment.

\section{Clustering methodology}

Clustering approach is a fundamental and important tool in statistical analysis. In the past, statistical clustering techniques have been widely used in such diverse scientific fields as psychology, zoology, biology, botany, sociology, meteorology, physiognomy, etc. (Anderberg, 1973; Yeh et al., 2000). It aims to group objects based on their similarities. There are two methods of clustering, the hierarchical clustering method, and the non-hierarchical method or K-means clustering. In the former, the number of clusters is obtained by automatic statistical analysis (Hong, 2003). Two types of hierarchical cluster methods are included, i.e., R type and Q 
type (Horváth, 2002; Yu and He, 2003). R type clustering is used for variables classification, and $Q$ type clustering for different cases.

In this study, the non-hierarchical clustering method, i.e., the K-means clustering was used to classify the rainfall events. This method is suitable for a large number of cases (Hong, 2003), and a cluster number is required before classification. To determine the number of clusters in a data set, numerous criteria were proposed (Perruchet, 1983). In our study, attempts were made until the most suitable clusters appeared. Normally, the classification must meet the ANOVA criterion of significant level $(P<0.05)$.

\section{Statistical analysis}

Fourteen years of consecutive data (1986-1999) were used in this study. In order to analyze the surface runoff and sediment loss, two indices including runoff coefficient (ratio of rainfall excess to rainfall) and erosion modulus were used

$C=(\mathrm{SR} / \mathrm{P}) \times \%$

where $C$, SR and $P$ denote runoff coefficient, surface runoff and precipitation, respectively.

$E_{\mathrm{m}}=\left(\mathrm{SL} / P_{\mathrm{A}}\right) n^{-1}$

where $E_{\mathrm{m}}, \mathrm{SL}, P_{\mathrm{A}}$ and $n^{-1}$ refer to erosion modulus, sediment loss, area of experimental plot and number of years, respectively.

All results were calculated with SPSS13.0 for windows.

\section{Results}

\section{Rainfall regimes}

Using K-means clustering, the 131 rainfall events were divided into three groups based upon three rainfall eigenvalues, including rainfall depth, duration and maximum 30-min intensity (Table 1).

In general, Rainfall Regime III has the highest values of mean rainfall depth and duration, followed by Rainfall Regime I and Rainfall Regime II. Mean maximum 30-min intensity, however, decreases in the order of Rainfall Regime II, Rainfall Regime I and Rainfall Regime III. Average rainfall eigenvalues represent the general characteristics of rainfall events. We thus conclude that Rainfall Regime II is the group of rainfall events with strong intensity, frequent occurrence of rainfall and very short duration, while Rainfall Regime III consists of rainfall events with low intensity, long duration and infrequent occurrence. Rainfall Regime I, however, is composed of rainfall events, which have moderate rainfall eigenvalues, i.e., higher intensity and shorter duration than Rainfall Regime III, but lower intensity and longer duration than Rainfall Regime II.

During the period of measurement, Rainfall Regime II occurred 89 times with a total of $1253 \mathrm{~mm}$ from May 1986 to September 1999. Rainfall Regime I occurred 36 times with a total of $962 \mathrm{~mm}$. Rainfall Regime III, however, was observed only 6 times.

The distributions of three rainfall regimes in different years varied (Fig. 2). Fig. 2(a) shows the total depths of the three rainfall regimes in different years. In most years, the rainfall regime sequence was Rainfall Regime II > Rainfall Regime I > Rainfall Regime III, except for 1986, 1993 and 1999, when Rainfall Regime I had higher values than Rainfall Regime II. This was because the frequency of Rainfall Regime I were the highest (Fig. 2(b)). Fig. 2(c) shows that the mean maximum 30-min intensity of Rainfall Regime II was the highest, followed by Rainfall Regimes I and III.

Generally, the regime and distribution of local rainfall are highly varied in different years. Rainfall Regime III, for example, most obviously shows the highest inter-annual variations. All six occurrences appeared in 1989, 1990, 1993, 1995, 1996, and 1999, respectively. No such rainfall events appeared in the other years.

\section{Soil and water loss in different land use types}

Mean runoff and soil losses differ among different land use types based on 14 years of measurements (Table 2). Cropland has the highest surface runoff and soil erosion, far more than those in the other four land use types. Second is pastureland, followed by woodland and grassland, then shrubland. It was found that both mean runoff coefficients and mean erosion moduli showed similar changing trend among the five land use types (Table 2).

In Table 3, the criterion for soil erosion classification, given by the Ministry of Water Resources of China (SL190-96) based on the mean annual erosion modulus, was used. It was

Table 1 Statistical features of different rainfall regimes

\begin{tabular}{lllclll}
\hline Rainfall regime & Eigenvalue & Mean & Standard deviation & Variation coefficient & Sum & Frequency (times) \\
\hline & $P(\mathrm{~mm})$ & 26.72 & 9.68 & 0.36 & 962 & 36 \\
& $D(\mathrm{~min})$ & 932 & 209 & 0.22 & 33,563 & - \\
II & $I_{30}(\mathrm{~mm} / \mathrm{min})$ & 0.14 & 0.12 & 0.86 & 1253 & 89 \\
& $P(\mathrm{~mm})$ & 14.09 & 7.87 & 0.56 & 19,190 & \\
& $D(\mathrm{~min})$ & 216 & 166 & 0.77 & - & 6 \\
III & $I_{30}(\mathrm{~mm} / \mathrm{mn})$ & 0.26 & 0.17 & 0.65 & 191 & 6 \\
& $P(\mathrm{~mm})$ & 31.75 & 7.44 & 0.23 & 10,420 &
\end{tabular}

$P, D, I_{30}$ separately represents precipitation depth, duration and maximum 30 -min intensity. 

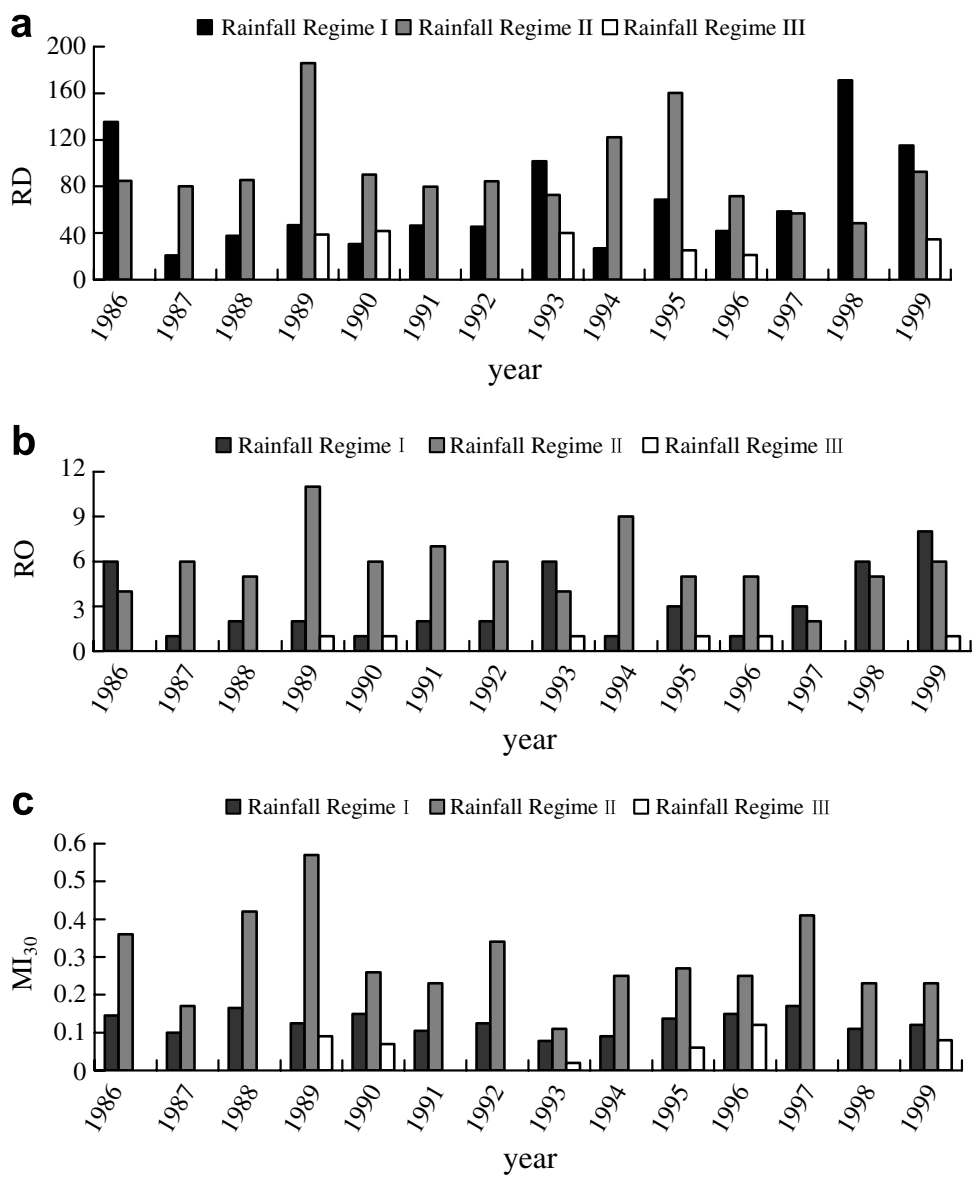

Figure 2 Characteristics of three rainfall regimes in different years. Note: RD, rainfall depth (mm); RO, rainfall occurrences (times); $\mathrm{Ml}_{30}$, maximum 30-min rainfall intensity $(\mathrm{mm} / \mathrm{min})$. Meanwhile, in some years no data are shown for Rainfall Regime III, and it is because this kind of rainfall did not occur during these years.

Table 2 Average 14-year runoff and soil erosion indexes in the study area

\begin{tabular}{llllll}
\hline Indexes & Cropland & Pastureland & Shrubland & Woodland & Grassland \\
\hline Runoff coefficient $(\%)$ & 8.40 & 7.16 & 2.61 & 5.46 & 3.91 \\
Erosion modulus $\left(\mathrm{t} \mathrm{km}^{-2} \mathrm{a}^{-1}\right.$ ) & 8599 & 3392 & 131 & 760 & 534 \\
\hline
\end{tabular}

Table 3 Criterion of soil erosion severity classification on the loess Plateau

\begin{tabular}{lllllll}
\hline Level & Feeble & Gentle & Middle & Intense & Highly intense & Severe \\
\hline Mean erosion modulus $\left(\mathrm{t} \mathrm{km}^{-2} \mathrm{a}^{-1}\right)$ & $<1000$ & $1000-2500$ & $2500-5000$ & $5000-8000$ & $8000-15,000$ & $>15,000$ \\
\hline
\end{tabular}

found that cropland has a very high erosion modulus $\left(8599 \mathrm{t} \mathrm{km}^{-2} \mathrm{a}^{-1}\right)$, higher than the lower boundary of highly intense erosion $\left(8000 \mathrm{t} \mathrm{km}^{-2} \mathrm{a}^{-1}\right)$. Pastureland, however, has a medium soil erosion level, and the other three land uses have a feeble level. Shrubland is best for soil and water control, with a $131 \mathrm{t} \mathrm{km}^{-2} \mathrm{a}^{-1}$ erosion modulus, which can even be neglected in most cases.

The role of mean annual runoff and erosion effects among different land use types in different years were captured by line-drawing method under SPSS13.0 (see Fig. 3). Fig. 3 shows the mean annual runoff coefficients and erosion moduli from 1986 to 1999. Runoff coefficients and erosion moduli differ in different years. For instance, the lowest and highest runoff coefficients of cropland were 1.84 in 1991 and 8.79 in 1986, respectively. The other land use types had the same characteristics in surface runoff and erosion moduli. However, the lower and peak value of surface runoff coefficient and erosion moduli in different land use types were not synchronous. In most years, runoff and soil loss ranked in order of: cropland $>$ pastureland $>$ woodland $>$ grassland $>$ shrubland. Pastureland (alfalfa), however, had the highest runoff coefficient in 1994 and 1995, 

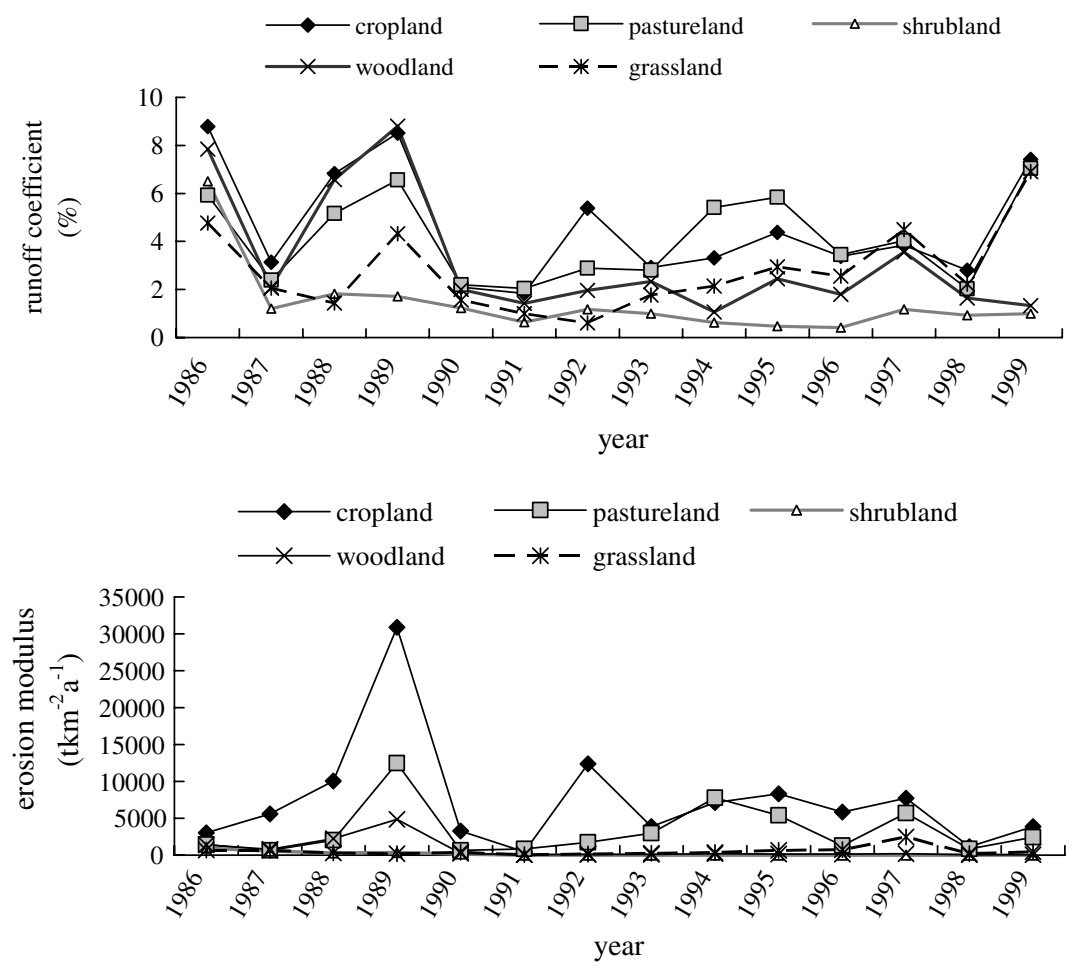

Figure 3 Mean soil and water losses under different land uses over the period of 1986-1999.

and the highest erosion modulus in 1994. Woodland had a higher runoff coefficient and a lower erosion modulus than cropland in 1989, and grassland had the highest runoff coefficient in 1997.

\section{Soil and water loss of different rainfall regimes}

The characteristics of runoff and soil loss under these three rainfall regimes are indicated in Fig. 4 . We found that the values of the runoff coefficients and erosion moduli among different land use types were as follows: Rainfall Regime II > Rainfall Regime I > Rainfall Regime III. Rainfall Regime II created the most runoff and soil erosion, far more than that in Rainfall Regime I. Rainfall Regime III, however, created little runoff and erosion.

Furthermore, the effects of land use on runoff and erosion in different years were also captured (Figs. 5 and 6). From 1986 to 1999 , different land use types had different responses to rainfall regimes. We found that runoff coefficients and erosion moduli fluctuated greatly over time in Rainfall Regime II, followed by Rainfall Regime I and Rainfall Regime III.

From 1986 to 1999, different land use types indicated various changing trends. Cropland and pastureland showed similar fluctuations among different years. Shrubland showed clearly decreasing trends in Rainfall Regime II, but not in Rainfall Regime I and Rainfall Regime III. Woodland had a sensitive response to Rainfall Regime II. Grassland, however, had a complex dynamic than did the other land use types. Its runoff coefficient varied irregularly under Rainfall Regimes I and II. Nevertheless, its erosion moduli under Rainfall Regime II were higher for several years, and then decreased sharply like those of shrubland and wood- land. No decreasing trends were found in the other two rainfall types.

\section{Discussion}

\section{Effects of land uses on runoff and soil loss}

In this study we found that runoff and soil loss varied among land use types (Table 2 ). This was explained in various ways by different scholars. First of all, vegetation canopy was thought to play a key role in protecting surfaces from erosion (Hovius, 1998; Karvonen et al., 1999; Xu, 2005; Pizarro et al., 2006). For example, Hou et al. (1996) found that when the coverage rate of vegetation increased from $10 \%$, to $28 \%, 56 \%$ and $60 \%$, soil erosion decreased from $1523 \mathrm{t} \mathrm{km}^{-2}$ to $527 \mathrm{t} \mathrm{km}^{-2}, 218 \mathrm{t} \mathrm{km}^{-2}$ and $107 \mathrm{t} \mathrm{km}^{-2}$, respectively. Zhou et al. (2006) also found that soil erosion was negatively linearly correlated with vegetation coverage $(r=0.99)$ in the loess hilly area. Other studies also draw the similar conclusions (Gyssels et al., 2005).

Secondly, it was recognised that litter production and organic matter accumulation could reduce soil-water loss (Eagleson, 1982; Boer and Puigdefábregas, 2005). Litter not only directly protects the surface soil from splash erosion, weakens the kinetic energy of raindrop, and slows runoff velocities, but also conserves surface rainwater due to its strong moisture holding capacity (Hou et al., 1996). Zhu et al. (2002) found that litter depth differed among land use types, and could intercept $6-13 \%$ of total rainfall amount. Meanwhile, studies show that litter contributes to humus formation, increased surface roughness, and decreased runoff generation thresholds (Descheemaeker et al., 2006). 

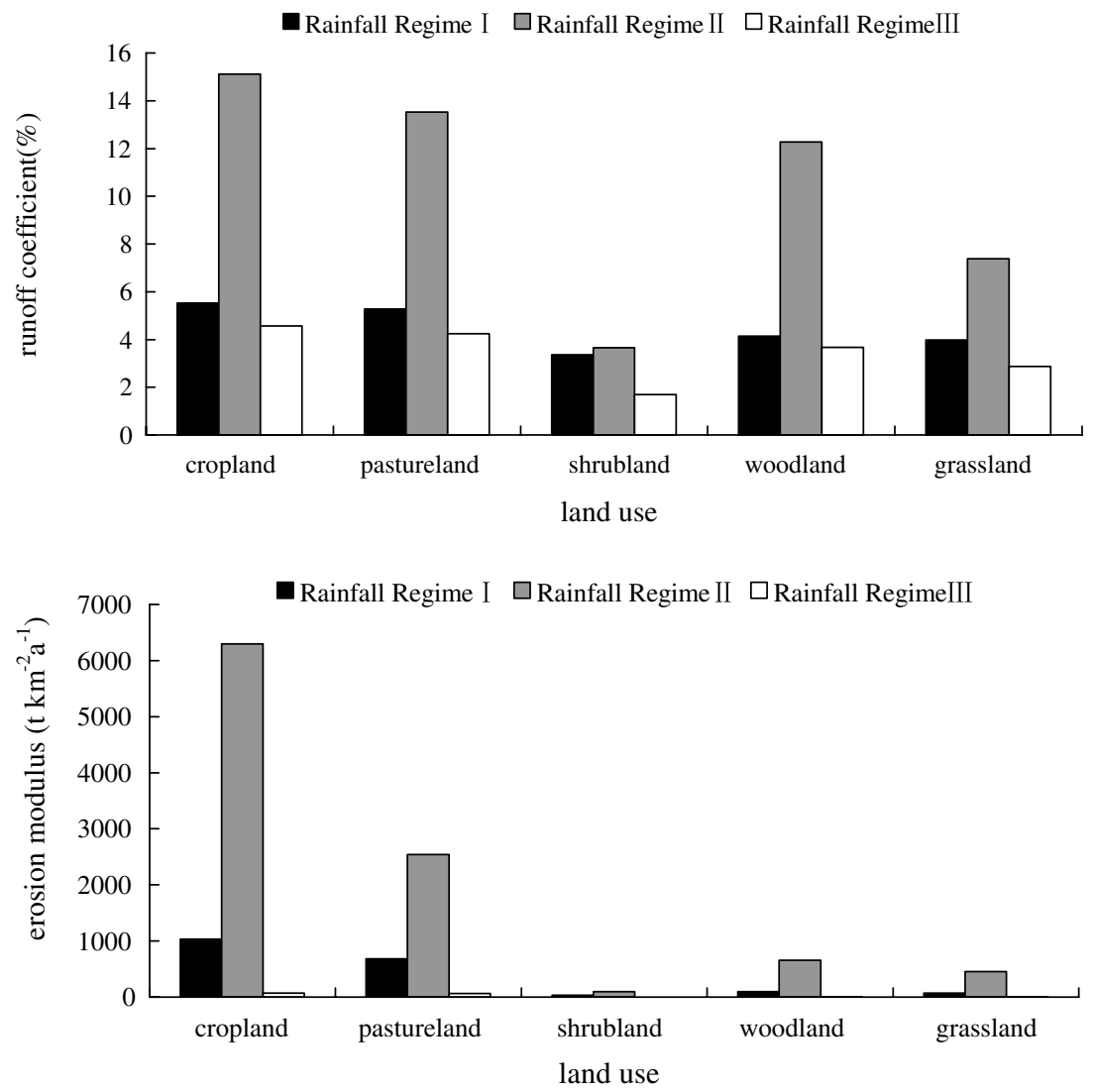

Figure 4 Features of runoff and erosion of five land uses under different rainfall regimes.

Thirdly, plant roots can decrease soil and water loss by increasing soil anti-scouribility, soil anti-shear strength and enhancing penetrability (Hou, 1990; Famiglietti et al., 1998; Mao et al., 2006). Meanwhile, roots may form a dense network (e.g., grass roots in topsoil) that physically binds soil particles, and the soil-root matrix has proven to be stronger than the soil or roots separately (Gyssels et al., 2005). A mechanical barrier to soil and water movement is thus created (Gyssels et al., 2002; De Baets et al., 2006). Yun et al. (2006) reports that root systems can loosen soil, enhance its porosity, and thus reduce runoff and erosion.

Lastly, human activities play an important role in runoff and soil erosion (Poesen et al., 2001; Ruysschaert et al., 2005). In our study, because of its high density (Table 4) and prickliness, shrubland is seldom disturbed by human activity. Cropland however, is strongly affected by human disturbance (e.g., sown in April and harvested at the end of July), which disturbs the soil layer and reduces land coverage.

Alfalfa (Medicago sativa L.) is widely cultivated since it has a high yield, wide adaptability and high drought tolerance (Li, 2002; Yu et al., 2006). As the major plant species of pastureland, however, alfalfa has a poor effect on soil and water conservation (Table 2 ). There are two reasons for this. Firstly, alfalfa is often harvested by local farmers for animal use. It results in the destruction of alfalfa, making soil sensitive to erosion. Secondly, alfalfa absorbs water from deep soil layers creating dry soil layers (Hou et al., 1999; Wang et al., 2003), which leads to plant degradation
(Grimes et al., 1992; Jia et al., 2006). This is unhelpful to soil and water conservation. From this point of view, large-scale alfalfa plantation is thus not recommended for semi-arid areas.

\section{Response of runoff and soil loss to different rainfall regimes}

According to our study, Rainfall Regime II is the most frequent rainfall events. It has a destructive effect on the soil surface and tends to induce higher runoff and erosion. Other researchers have reported this as well (Zhu and Ren, 1992; Zheng et al., 2005). Rainfall Regime III constitutes only a small portion of total rainfall events and has slightly erosive effects on soil. Hence, it cannot produce severe erosion and water loss. This means that the response of runoff and erosion to land uses is most sensitive to Rainfall Regime II, then Rainfall Regime I, followed by Rainfall Regime III.

Under Rainfall Regime II, the runoff and soil losses of land use types, such as shrubland and woodland decreased as plants grew. In the first 3-4 years after plantation, runoff and erosion were very serious (even higher than cropland and pastureland in some years), then the runoff coefficients and erosion moduli decreased sharply, and finally reached a relatively stable low level after 1990 (Figs. 5 and 6). This phenomenon is similar to that observed in several former studies (Hou et al., 1995, 1996; Li and Shao, 2006).

We found that the decreasing trend under Rainfall Regime II is closely related to plant succession. According to 

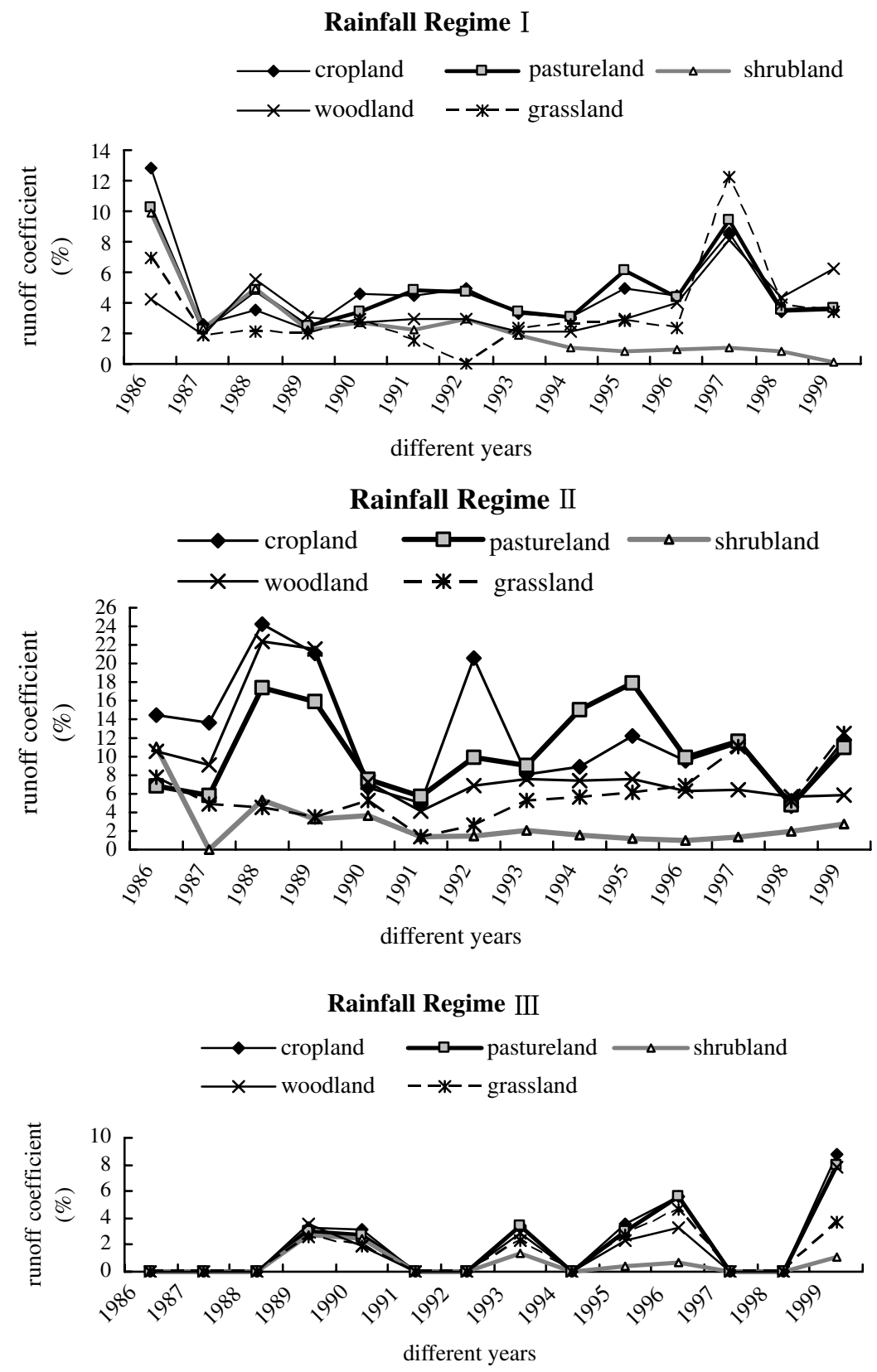

Figure 5 Inter-annual runoff coefficients under different rainfall regimes.

local investigation, vegetation coverage of shrubland and woodland gradually increased with plant growth (Table 4), while runoff and erosion decreased. Other authors have also drawn similar conclusions. For example, based on consecutive experiments in a hilly loess area, Hou et al. (1996) found that plant succession could gradually increase coverage rate, accumulate litter layer, and improve soil properties, which notably reduced runoff and soil erosion with plant evolution. Zou et al. (2000) indicated that a significant correlation ( $r=0.998)$ between root amounts and fixed soil amount existed, and root amounts increased quickly with plant growth. The measured runoff and erosion reduction, therefore, actually result from the combined effect of both above-ground (canopy, stems and leaves, and litter layers) and below-ground (roots) biomass (Gyssels et al., 2005; De Baets et al., 2006).
The decreasing trend shown under Rainfall Regime II, however, did not exist in Rainfall Regimes I and III. This was mainly due to lower rainfall intensity in these two rainfall regimes, whereas the mean precipitation depth and duration of single rainfall events under these two regimes are higher than those under Rainfall Regime II (Table 2). From this standpoint, rainfall intensity is the most important indicator in predicting or indicating degrees of soil erosion, although other eigenvalues such as rainfall depth and duration are indispensable to determine rainfall types. Other studies also confirmed that rainfall intensity play ed a vital role in runoff and sediment generation (Jiao et al., 1999; de Lima and Singh, 2002 de Lima et al., 2003). Furthermore, rainfall frequency is also very important (Table 2 ). Low frequency combined with weak intensity can result in less soil loss, especially under Rainfall Regime III. 

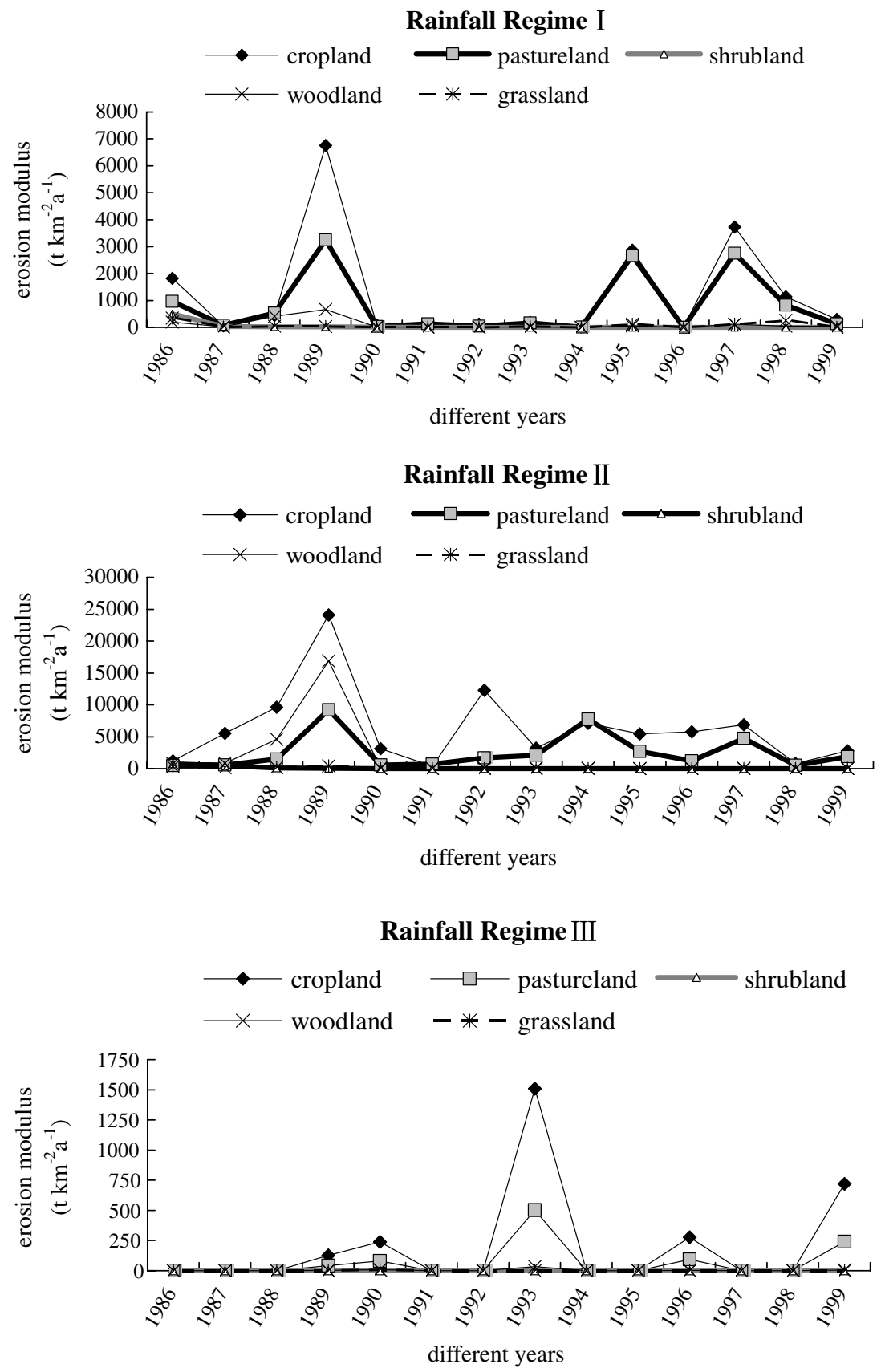

Figure 6 Inter-annual erosion moduli under different rainfall regimes.

\section{Process of soil and water loss under the interaction of land use and rainfall regime}

Our study indicates that comprehensive inter-relationships exist between rainfall, land use/vegetation cover and soil and water loss (Figs. 5 and 6). Due to the influence of land cover types and vegetation development dynamics, the relationship between rainfall and the process of overland flow and soil loss becomes uncertain. On the one hand, rainfall is a destructive force to the land surface making the soil prone to splash erosion (Jackson, 1975; Jiao et al., 1999; Salles and Poesen, 2000; Dijk et al., 2002). On the other hand, land use/vegetation cover has positive effects on the surface (Braud et al., 2001), which plays a significant role in the accumulation of fine particles and protecting soil surface from erosion (Bradshaw, 1997, 2000).

Generally, our results indicate two cases. In the first one, soil and water loss is dominated by rainfall itself, and land use/vegetation plays a less important role, i.e., the runoff and soil loss are controlled by rainfall erosivity rather than by erosion-resistance of land use and vegetation cover (Xu, 2005). According to our study, the responses of runoff and erosion in this case are sensitive to the rainfall regimes, especially to Rainfall Regime II (Figs. 5 and 6). Due to poor surface coverage and other factors such as human disturbance, cropland, pastureland, the initial sapling stages of shrubland and woodland both belong to the first case. 
Table 4 Mean annual vegetation coverage rate (\%) of land uses in different years

\begin{tabular}{|c|c|c|c|c|c|}
\hline Year & Cropland & Pastureland & Shrubland & Woodland & Grassland \\
\hline 1986 & 50 & 90 & 40 & 15 & 80 \\
\hline 1987 & 57 & 85 & 60 & 24 & 85 \\
\hline 1988 & 52 & 75 & 95 & 37 & 100 \\
\hline 1989 & 62 & 45 & 98 & 39 & 100 \\
\hline 1990 & 68 & 40 & 99 & 45 & 100 \\
\hline 1991 & 53 & 50 & 99 & 55 & 98 \\
\hline 1992 & 43 & 40 & 99 & 65 & 95 \\
\hline 1993 & 36 & 40 & 99 & 70 & 93 \\
\hline 1994 & 30 & 35 & 99 & 74 & 93 \\
\hline 1995 & 30 & 38 & 99 & 78 & 90 \\
\hline 1996 & 35 & 40 & 99 & 80 & 87 \\
\hline 1997 & 46 & 40 & 99 & 82 & 85 \\
\hline 1998 & 70 & 35 & 99 & 84 & 85 \\
\hline 1999 & 67 & 50 & 99 & 86 & 80 \\
\hline
\end{tabular}

Measurement: The herbaceous coverage was estimated in the maximum growth period by 5 quadrates of $1 \mathrm{~m} \times 1 \mathrm{~m}$ within each plot; the coverage of seabuckthorn and Chinese pine was calculated by means of the measured values of canopy width. The mean value of three replications was used to represent coverage rate of each land use.

In the second case, soil and water loss are dominated by vegetation/land use, and the effect of the rainfall regime is slight, then the runoff and soil erosion are insensitive to rainfall and its regimes. The coverage rate of shrubland (Hippophae rhamnoides L.) reached 99\% after 1990 (Table 4), which decreased runoff and erosion significantly, and induced less sensitivity to rainfall. Xu (2005) also indicated that vegetation cover can protect surface soil from erosion. Meanwhile, other studies have also found that vegetation succession can improve soil physiochemical properties and hence lower erodibility (Douglas, 1967; Hou et al., 1996; Kosmas et al., 1997; Coppus et al., 2003; Li and Shao, 2006). After several years' growth (after 1990, in Figs. 5 and 6) therefore, the runoff and soil erosion of shrubland (Hippophea rhamnoides L.) and woodland (Pinus tabulaeformis Carr.) decreased and kept at a lower level. This situation resembles the second case.

\section{Conclusion and suggestion}

In this study, three rainfall regimes were classified using $\mathrm{K}$ means clustering based on rainfall depth, intensity and duration. Rainfall Regime II is the dominant aggregation of rainfall events, which have such features as high intensity, short duration and high frequency. Rainfall Regime I is the aggregation of rainfall events of medium intensity, duration and frequency. Rainfall Regime III is the aggregation of rainfall events of weak intensity, long duration and low frequency.

Results showed that the runoff and soil losses of different land uses varied greatly under different rainfall regimes. Generally, runoff and sediment loss under Rainfall Regime II were greatest, followed by Rainfall Regimes I and III. Furthermore, the runoff coefficient and erosion modulus of shrubland were lowest, followed in increasing order by grassland and woodland. Pastureland had an unsatisfactory erosion control effect, slightly weaker than cropland and far greater than the other three land use types.

Under Rainfall Regime II, shrubland and woodland showed clearly that runoff and sediment yields decrease quickly with plant growth. Runoff and erosion were very severe during the first 3-4 years after plantation, then decreased and stabilized at a low level. This indicates that the growth periods of plant species in each land use play pivotal roles in resisting surface runoff and soil erosion.

The findings in this study have important implications for surface runoff and soil loss control in the semi-arid loess hilly area. Firstly, different practical countermeasures should be laid out according to rainfall types. More attention should be paid to the seasonal distribution of the most erosive rainfall type in further studies, and effective measures need to be taken to control its destructive effects. Secondly, in order to control soil erosion, the most suitable land use types can be selected based on scientific observation. Scrubland (e.g., seabuckthorn) should be recommended as the first key plant species in land use adjustment and vegetation restoration. Grassland and woodland, however, can be used as important supplement to shrubland. Meanwhile, results indicate large-scale plantation of alfalfa should be avoided. More studies should focus on the relationship between alfalfa's water exhaustion and its erosion control ability. Thirdly, more attention must be paid to the plants' succession stages. Due to severe runoff and soil loss at the initial sapling stages after planting (or seeding), other measures such as straw mulch, plastic film or prevention of human disturbance should be taken into account.

\section{Acknowledgements}

The authors thank the Dingxi Institute of Soil and Water Conservation in Gansu province for providing experimental plots and pure-hearted field assistance. Sincere thanks are also expressed to Gansu Research Institute of Forestry. Ms. Victoria Wilhoite, at the University of South Florida School of Library and Information Science, is acknowledged for her valuable comments and English improvement. The authors express their appreciation to the reviewers by 
whose constructive remarks this paper has been improved. This research was supported by National Natural Science Foundation of China (40321101; 90502007) and the National Advanced Project of the Tenth Five-year Plan of China (2001BA606A-03).

\section{References}

Aizen, V., Aizen, E., Glazirin, G., 2000. Loaiciga simulation of daily runoff in Central Asian alpine watersheds. Journal of Hydrology 238, $15-34$.

Anderberg, M.R., 1973. Cluster Analysis for Applications. Academic Press Inc., New York.

Bochet, E., Rubio, J.L., Poesen, J., 1999. Modified topsoil islands within patchy Mediterranean vegetation in SE Spain. Catena 38, 23-44.

Boer, M., Puigdefábregas, J., 2005. Effects of spatially structured vegetation patterns on hill-slope erosion in a semiarid Mediterranean environment: a simulation study. Earth Surface Processes and Landforms 30, 149-167.

Bradshaw, A., 1997. Restoration of mined lands-using natural processes. Ecological Engineering 8, 255-269.

Bradshaw, A., 2000. The use of natural processes in reclamationadvantages and difficulties. Landscape and Urban Planning 51, 89-100.

Braud, I., Vich, A.I.J., Zuluaga, J., 2001. Vegetation influence on runoff and sediment yield in the Andes region: observation and modeling. Journal of Hydrology 254, 124-144.

Bürger, G., 2002. Selected precipitation scenarios across Europe. Journal of Hydrology 262, 99-110.

Chen, L., Wang, J., Fu, B., Qiu, Y., 2001. Land use change in a small catchment of northern Loess Plateau, China. Agriculture, Ecosystem and Environment 86, 163-172.

Chen, L., Messing, I., Zhang, S., 2003. Land use evaluation and scenario analysis towards sustainable planning on the Loess Plateau in China-case study in a small catchment. Catena 54, 303-316.

Coppus, R., Imeson, A.C., Sevink, J., 2003. Identification, distribution and characteristics of erosion sensitive areas in three different Central Andean ecosystems. Catena 51, 315-328.

Costa, M.H., Botta, A., Cardille, J.A., 2003. Effects of large scale changes in land cover on the discharge of the Tocantins River, Southeastern Amazonia. Journal of Hydrology 283 (4), 206-217.

De Baets, S., Poesen, J., Gyssels, G., Knapen, A., 2006. Effects of grass roots on the erodibility of topsoils during concentrated flow. Geomorphology 76, 54-67.

de Lima, J.L.M.P., Singh, V.P., 2002. The influence of the pattern of moving rainstorms on overland flow. Advances in Water Resources 25, 817-828.

de Lima, J.L.M.P., Singh, V.P., Isabel, M., 2003. The influence of storm movement on water erosion: storm direction and velocity effects. Catena 52, 39-56.

Descheemaeker, K., Muys, B., Nyssen, J., Poesen, J., Raes, D., Haile, M., Deckers, J., 2006. Litter production and organic matter accumulation in exclosures of the Tigray highlands, Ethiopia. Forest Ecology and Management 233 (1), 21-35.

Dijk, A.I.J.M., Bruijnzeel, L.A., Rosewell, C.J., 2002. Rainfall intensity-kinetic energy relationships: a critical literature appraisal. Journal of Hydrology 261, 1-23.

Douglas, I., 1967. Man, vegetation and sediment yield of river. Nature 215, 925-928.

Eagleson, P.S., 1982. Ecological optimality in water-limited natural soil-vegetation systems, 1 . Theory and hypothesis. Water Resources Research 18, 325-340.

Elsen, E., Hessel, R., Liu, B., 2003. Discharge and sediment measurements at the outlet of a watershed on the Loess plateau of China. Catena 54, 147-160.
Endale, D.M., Fisher, D.S., Steiner, J.L., 2006. Hydrology of a zeroorder Southern Piedmont watershed through 45 years of changing agricultural land use. Part 1 . Monthly and seasonal rainfallrunoff relationship. Journal of Hydrology 316, 1-12.

Famiglietti, J.S., Rudnicki, J.W., Rodell, M., 1998. Variability in surface moisture content along a hillslope transect: Rattlesnake Hill, Texas. Journal of Hydrology 210, 259-281.

FAO-UNESCO, 1974. Soil map of the world (1:5000 000). Food and agriculture organization of the United Nations, UNESCO, Paris.

Flanagan, D., 2002. In: Lal, R. (Ed.), Erosion Encyclopedia of Soil Science. Marcel Dekker, New York, pp. 395-398.

Fu, B., 1989. Soil erosion and its control in the Loess Plateau of China. Soil Use and Management 5, 76-82.

Fu, B., Gulinck, H., 1994. Land evaluation in an area of severe erosion: the Loess Plateau of China. Land Degradation and Development 5, 33-40.

Govers, G., Everaert, W., Poesen, J., Rauws, G., De Ploey, J., Latridou, J.P., 1990. A long flume study of the dynamic factors affecting the resistance of a loamy soil to concentrated flow erosion. Earth Surface Processes and Landforms 11, 515-524.

Grimes, D.W., Wiley, P.L., Sheesley, W.R., 1992. Alfalfa yield and plant water relations with variable irrigation. Crop Science 32 , 1381-1387.

Gyssels, G., Poesen, J., Nachtergaele, J., Govers, G., 2002. The impact of sowing density of small grains on rill and ephemeral gully erosion in concentrated flow zones. Soil and Tillage Research 64, 189-201.

Gyssels, G., Poesen, J., Bochet, E., Li, Y., 2005. Impact of plant roots on the resistance of soils to erosion by water: a review. Progress in Physical Geography 29 (2), 189-217.

Hong, N. (Ed.), 2003. Products and Servicing Solution Teaching Book for SPSS of Windows Statistical. Tsinghua University Press, and Beijing Communication University Press, Beijing, pp. 300-311 (in Chinese with English abstract).

Horváth, Sz., 2002. Spatial and temporal patterns of soil moisture variations in a sub-catchment of River Tisza. Physics and Chemistry of the Earth 27, 1051-1062.

Hou, X., 1990. Study on the benefits of plants to reduce sediment in the loess rolling gullied region of north Shaanxi. Bulletin of Soil and Water Conservation 10 (2), 33-40 (in Chinese with English abstract).

Hou, X., Bai, G., Cao, Q., 1995. Contrastive experiments on the soil penetrability and anti-scourability of Robinia pseudoacacia L., Hippophae rhamnoides L., Caragana korshinskii. Journal of Soil Water Conservation 9 (3), 90-95 (in Chinese with English Abstract).

Hou, X., Bai, G., Cao, Q., 1996. Study on benefits of soil and water conservation of forest and its mechanism in loess hilly region. Research of Soil and Water Conservation 3 (2), 98-103 (in Chinese with English Abstract).

Hou, Q., Han, R., Han, S., 1999. Primary studies on the soil dry layer issue of artificial woodland and grassland on the Chinese Loess Plateau. Soil and Water Conservation in China 5, 11-14 (in Chinese with English abstract).

Hovius, N., 1998. Controls on sediment supply by large rivers, relative role of Eustasy, climate, and tectonism in continental rocks. Society of Sedimentary Geology 59, 3-16 (Special Publication).

Huang, Y., Chen, L., Fu, B., Huang, Z., Gong, J., 2005. The wheat yield and water-use efficiency in the Loess Plateau: straw mulch and irrigation effects. Agricultural Water Management 72, 209222.

Jackson, I.J., 1975. Relationship between rainfall parameters and interception by tropical forest. Journal of Hydrology 24, 215238.

Jia, Y., Li, F., Wang, X., Yang, S., 2006. Soil water and alfalfa yields as affected by alternating ridges and furrows in rainfall harvest in a semiarid environment. Field Crops Research 97, 167-175. 
Jiao, J., Wang, W., Hao, X., 1999. Precipitation and erosion features of rainstorms in different patterns on the Chinese Loess Plateau. Journal of Arid Land Resources and Environment 13 (1), 34-41 (in Chinese with English abstract).

Karvonen, T., Koivusalo, H., Jauhiainen, M., 1999. A hydrological model for predicting runoff from different land use areas. Journal of Hydrology 217, 253-265.

Kinnell, P.I.A., 2005. Raindrop-impact-induced erosion processes and prediction: a review. Hydrological Processes 19, 2815-2844.

Kirkby, M.J., Bracken, L.J., Shannon, J., 2005. The influence of rainfall distribution and morphological factors on runoff delivery from dryland catchments in SE Spain. Catena 62, 136-156.

Kosmas, C., Danalatos, N., Cammeraat, L.H., 1997. The effect of land use on runoff and soil erosion rates under Mediterranean conditions. Catena 29, 45-59.

Kosmas, C., Gerontidis, St., Marathianou, M., 2000. The effect of land use change on soils and vegetation over various lithological formations on Lesvos (Greece). Catena 40, 51-68.

$\mathrm{Li}, \mathrm{Y} ., 2$ 2002. Productivity dynamic of alfalfa and its effects on water eco-environment. Journal of Pedology 39 (3), 404-411 (in Chinese with English abstract).

Li, Y., Shao, M., 2006. Changes of soil physical properties under long-term natural vegetation restoration in the Loess Plateau of China. Journal of Arid Environment 64, 77-96.

Li, F., Cook, Geballe, S.G.T., Burch, W.R., 2000. Rainwater harvesting agriculture: an integrated system for water management on rainfed land in China's semiarid areas. AMBIO 29 (8), 477-483.

Licznar, P., Nearing, M.A., 2003. Artificial neural networks of soil erosion and runoff prediction at the plot scale. Catena 51, 89114.

Luk, S-H., Abrahams, A.D., Parsons, A.J., 1986. A simple rainfall simulator and trickle system for hydro-geomorphological experiments. Physical Geography 7 (4), 344-356.

Luk, S.H., Chen, H., Cai, Q., Jia, Z., 1989. Spatial and temporal variations in the strength of loess soils, Lishi, China. Geoderma 45, 303-317.

Madden, L.V., Wilson, L.L., Ntahimpera, N., 1998. Calibration and evaluation of an electronic sensor for rainfall kinetic energy. Phytopathology 88 (9), 950-959.

Mao, R., Meng, G., Zhou, Y., 2006. Mechanism of plant roots on soil erosion control. Research of Soil and Water Conservation 13 (2), 241-243 (in Chinese with English abstract).

Mathys, N., Klotz, S., Esteves, M., 2005. Runoff and erosion in the Black Marls of the French Alps: observations and measurements at the plot scale. Catena 63, 261-281.

Mazi, K., Koussis, A.D., Restrepo, P.J., 2004. Erratum to "A groundwater-based, objective-heuristic parameter optimisation method for a precipitation-run-off model and its application to a semi-arid basin"' [Journal of Hydrology 290 (2004) 243-258]. Journal of Hydrology 299, 160-161.

Morin, E., Goodrich, D.C., Maddox, R.A., 2006. Spatial patterns in thunderstorm rainfall events and their coupling with watershed hydrological response. Advances in Water Resources 29 (6), 843-860.

Nearing, M.A., 2001. Potential changes in rainfall erosivity in the US with climate change during 21st century. Journal of Soil and Water Conservation 56 (3), 229-232.

Nearing, M.A., Govers, G., Norton, D.L., 1999. Variability in soil erosion data from replicated plots. Soil science Society of America Journal 63 (6), 1829-1835.

Nearing, M.A., Jetten, V., Baffaut, C., 2005. Modeling response of soil erosion and runoff to changes in precipitation and cover. Catena 61, 131-154.
Perruchet, C., 1983. Constrained agglomerative hierarchical classification. Pattern Recognition 16 (2), 213-217.

Pizarro, R., Araya, S., Jordán, C., Farías, C., Flores, J.P., Bro, P.B., 2006. The effects of changes in vegetative cover on river flows in the Purapel river basin of central Chile. Journal of Hydrology 327, 249-257.

Poesen, J.W.A., Verstraeten, G., Soenens, R., Seynaeve, L., 2001. Soil losses due to harvesting of chicory roots and sugar beet: an underrated geomorphic process? Catena 43, 35-47.

Ruysschaert, G., Poesen, J., Verstraeten, G., 2005. Inter-annual variation of soil losses due to sugar beet harvesting in West Europe. Agriculture, Ecosystems and Environment 107, 317-329.

Salles, C., Poesen, J., 2000. Rain properties controlling soil splash detachment. Hydrological Processes 14, 271-282.

Sharma, P.P., Gupta, S.C., Foster, G.R., 1993. Predicting soil detachment by raindrops. Soil Science Society of America Journal 57, 674-680.

Singha, R., Tiwarib, K.N., Malb, B.C., 2006. Hydrological studies for small watershed in India using the ANSWERS model. Journal of Hydrology 318, 184-199.

Siriwardena, L., Finlayson, B.L., McMahon, T.A., 2006. The impact of land use change on catchment hydrology in large catchment: The Comet River, Central Queensland, Australia. Journal of Hydrology 326, 199-214.

Wang, Z., Liu, B., Lu, B., 2003. A study on water restoration of dry soil layers in the semi-arid area of Loess Plateau. Acta Ecologica Sinica 23 (9), 1944-1950 (in Chinese with English abstract).

$\mathrm{Xu}, \mathrm{J} ., 2$ 2005. Precipitation-vegetation coupling and its influence on erosion on the Loess Plateau, China. Catena 64, 103-116.

Yeh, H.-Y., Wensel, L.C., Turnblom, E.C., 2000. An objective approach for classifying precipitation patterns to study climatic effects on tree growth. Forestry Ecology and Management 139, $41-50$.

Yu, J., He, X. (Eds.), 2003. Data Statistical Analysis and Application of SPSS Software. People's Post Press, Beijing, pp. 253-276 (in Chinese).

Yu, J., Li, F., Wang, X., Yang, S., 2006. Soil water and alfalfa yields as affected by altering ridges and furrows in rainfall harvest in a semiarid environment. Field Crop Research 97, 167-175.

Yun, X., Zhang, X., Li, J., Zhang, M., Xie, Y., 2006. Effects of vegetation cover and precipitation on the process of sediment produced by erosion in a small watershed of loess region. Acta Ecologica Sinica 26 (1), 1-8 (in Chinese with English abstract).

Zhang, X.C., Nearing, M.A., Risse, L.M., Gregaor, K.C., 1996. Evaluation of WEPP runoff and soil loss predictions using natural runoff plot data. Transaction of the ASAE 39 (3), 855863.

Zheng, F., He, X., Gao, X., Zhang, C., Tang, K., 2005. Effects of erosion patterns on nutrient loss following deforestation on the Loess Plateau of China. Agriculture, Ecosystems and Environment 108, 85-97.

Zhou, Z., Shangguan, Z., Zhao, D., 2006. Modeling vegetation coverage and soil erosion in the Loess Plateau Area of China. Ecological Modeling 198, 263-268.

Zhu, X., Ren, M., 1992. The shaping process and countermeasures of the Chinese Loess Plateau. Soil Conservation in China 2, 2-10 (in Chinese)

Zhu, J., Liu, J., Zhu, Q., Wu, Q., 2002. Hydro-ecological functions of forest litter layers. Journal of Beijing Forestry University 24, 30-34 (in Chinese with English abstract).

Zou, D., Yu, T., Zhou, Q., Yang, S., 2000. Mechanism of soil and water conservation and its benefit of Eulaliopsis binata. Research of Agricultural Modernization 21 (4), 210-213 (in Chinese with English abstract). 